\title{
Migration and Its Discontents: A Postcolonial Rendering of NoViolet Bulawayo's We Need New Names
}

\author{
Mamadou Abdou Babou Ngom (Corresponding author) \\ English Department, Cheikh Anta Diop University of Dakar, Senegal, West Africa \\ Email: mamadou35.ngom@ucad.edu.sn
}

Received: 07/04/2020

Accepted: 10/06/2020

Published: 01/07/2020

Volume: 1 Issue: 2

How to cite this paper: Ngom, M.A.B. (2020). Migration and Its Discontents: A Postcolonial Rendering of NoViolet Bulawayo's We Need New Names. Journal of Critical Studies in Language and Literature, 1(2), 10-19

DOI: https://doi.org/10.46809/jcsll.v1i2.6

Copyright (C) 2020 by author(s) and Global Talent Academy Ltd. This work is licensed under the Creative Commons Attribution International License (CC BY 4.0).

http://creativecommons.org/licenses/by/4.0/

$$
\text { (c) (i) }
$$

\begin{abstract}
This research paper is my attempt, through a blow-by-blow analysis of a fictional work of a rising star in postcolonial writing, to grapple with the manifold discontents that attend the event of migration. Migration is an astoundingly painful experience to go through, whose multifaceted toll on the subject may be beyond repair. Using NoViolet Bulawayo's We Need New names as a stepping-stone, I argue that migration, albeit a time-honoured phenomenon has picked up speed in the twentieth-century and continued into the twenty-first century with a most heavy human toll. The paper emphasizes that even though the act of migration is underpinned by a hope for betterment, it may turn out to be a damp squid. No end of landmines and hiccups dot the migratory journey. The long-suffering postcolonial subject, hallmarked by the stifling strictures of marginality owing to a long history of race-based oppression that stretches back to the gruesome eras of the trans-Atlantic slave trade and colonization, is on the receiving end of the horrors of migration. I tap into key terms in postcolonial theory cum sociologyinformed perspectives to make a valid point about the dehumanizing fallout from the migratory experience.
\end{abstract}

Keywords: Migration, Hybridity, Interpolation, Postcolonial, Language, Belonging

\section{A Postcolonial Reading of Bulawayo's We Need New Names}

Within the framework of this study which aims to analyze the travails associated with the migratory experience, I predicate the theoretical section on the significance of 'home' and 'homeland' to a person's identity. This in an endeavour to better highlight the heart-rending thought process involved in the call to migrate for economically or politically-based reasons. The toll that goes with the territory of the migratory experience bears testimony as its manifold scars can be lifelong. As stated earlier, in a spirit to bolster up my case, I adopt an approach informed by postcolonial theory not to mention sociology and philosophy-based perspectives. There is no denying that migrant subjects represent the waifs and strays of departing countries. That is, folks who live in utter squalor with next to no off-ramp to betterment. And the role of the postcolonial writer (not least the African one) lies inter alia in his well-meaning move to flag up the plight of the voiceless, thereby shaming the legacy of colonialism as well as the crass failure of post-independence African leadership with an eye to effecting change. The Oxford Advanced Learner's Dictionary defines the words 'migration' as 'the movement of large numbers of people, birds or animals from one place to another" (8th Edition). Speaking of the Glossary on Migration, it describes migration as "a process of moving, either across an international border, or within a State. 
It is a population movement, encompassing any kind of movement of people, whatever its length, composition and causes" (41).

The phenomenon is a time-honoured one whose origins stretch far back in history: "For much of human history, the movement of peoples from one territory to another has been the norm: an endless search for new hunting grounds, new pastures, new sources of trade, new forms of work. Others have been forced to move as slaves or to escape wars" (Ramachandra 130). Instances are thick on the ground in human history of massive movements of people having elected to shake the dust off their countries only to go to another one in quest of a better life. Although the choice of displacement is oftentimes economic-based, other triggers such as political persecution, war, famine -you name it- can factor into it. Given the sanctity of 'homeland' in a person's life, it's safe to assume that migration is a heartrending experience. The sense of belonging and identity associated with 'homeland' gets subsumed in the act migration. In an article about the dynamics of migration processes and the concept of 'home', Sergey Mostivo underscores the purport of 'home' as crucial to 'values of attitudes and personality'. He writes that:

It is not so much a country that any migrant (forced or voluntary) leaves but their home as a set of certain psychological meanings, histories and values. Leaving "home", they lose behavioural and social roles, i.e., a part of their personal identity, which manifests itself to the world, first of all, on the border of social interaction. "Home" is the resource state of the individual, which expands itself in a particular situation or place, so that we feel our rootedness in being, we feel calm and comfortable. (1991)

The psychological cum physical distress attendant upon the weighty call to leave one's "home" takes a backseat to the utopian quest for making something of oneself that underpins the choice of displacement. Place attachment factors into the inefficiency of any pushback attempt against departure. Additionally, individuals caught in the toils of poverty or war or persecution of any ilk have their work cut resisting the tantalizing move to migrate. Migration features prominently in their scheme of things as a way out of a cheap life. Thus, the core motives for migration are explained in terms of push and pull factors. Sociologist Spickard underlines that the push factors refer to those "those elements of the social situation in the sending country that make individuals want to leave" whilst the pull factors are "those features that draw them to a particular destination" (115). These potent dyadic factors combine to blind the individual to the extremities of displacement. The travails of immigrant life are oftentimes cloaked under a veneer of chimerical perks purportedly on hand in the destination country. Plainly, the act of migration comes at a cost ${ }^{1}$. The human toll of displacement finds expression in the excruciatingly distressing emotional cum physical suffering attendant upon family separation, and, more significantly, the adaptation hassles to the new environment compounded by the utter disillusionment with the host country in terms of safe haven. Bill Ashcroft (2009) appositely sums up the human toll of displacement, and write that, "A valid and active sense of the self may have been eroded by dislocation resulting from migration, the experience of enslavement, transportation or voluntary removal for indentured labor" (8-9). The vexed issue of migration and its discontents is a glaring hallmark in postcolonial writing, not least postcolonial African one. Postcolonial literature can be read as a strenuous attempt by educated people from formerly colonized nations to push back against hegemonic versions of history that conceived of the indigenous African as an "other". Bart-Moore Gilbert delineates the scope of postcolonial criticism and posits that,

It is understood as preoccupied principally with analysis of cultural forms which mediate, challenge or reflect upon the relations of domination and subordination-economic, cultural, political-between (and often within) nations, races or culture, which characteristically have their roots in the history of modern European colonialism and imperialism and which, equally characteristically, continue to be apparent in the present era of neocolonialism. (12)

Postcolonial literature foregrounds the plight of the marginal as a scathing indictment of history. The task of postcolonial writers is, in no small measure, redemptive as they "are laying bare submerged histories, bringing minority interests and ethnic diversities to the forefront, reconfiguring cultural forms and ways of life previously relegated to the periphery" (Shands 13). Also, the issue of migration and its attendant multifaceted ravages is an ideal site for postcolonial writers to witheringly blast failed post-independence African leadership, hallmarked by a slew of on the hoof economic policies geared more towards the interests of former colonizing powers than those of erstwhile colonized nations, and a sickening lust for power. Indeed, misrule and mismanagement of public funds for purely self-serving ends factor into the steady movements of people (mostly young) from Africa to the west in quest of a better life. The espousal of migration as a core theme in postcolonial African fiction bespeaks a sense of despondency over a geographical phenomenon that has exacted a most heavy toll of African youth over the past few twenty years.

NoViolet Bulayo (1981-) is a United States-based Zimbabwean writer who earned her spurs as a writer with her 2013 debut novel, We Need New Names, thanks to which she won the Los Angeles Times Book Prize Art Seidenbaum Award plus the Hemingway Foundation/Pen Award as well as the Etisalat Prize for Literature. She has also had many other literary accolades conferred upon her. From an academic standpoint, Bulawayo is no mean achiever-that is, she earned a Bachelor's and Master's degrees in English from the University of Texas not to mention a Master of Arts in creative writing from Cornwell University. 
We Need New Names falls into the category of a literary genre known as "migrant literature", whose distinctive trademark is the recounting of the harrowing experience of migration. The book revolves around the life of Darling, an eleven-year-old girl who moves from her native Zimbabwe, where destitution and a relentless crackdown on any dissenting voice are a common occurrence, to the United States in search of a better life. From the perspective of Darling (who happens to be the narrator and protagonist), the grass is always greener on the other side of the fence. Hence her stubborn wish to join her aunt in the States. The level of suck in Paradise, an ironically named shantytown that arguably serves as a metaphor for Zimbabwe, is such that Darling and a bunch of friends live off stealing guavas in a posh district whose denizens are mainly white-that is, Budapest. The female voice's description of Budapest in glowing terms, "This place is not like Paradise, it's like being in a different country altogether. A nice country where people who are not like live" (6), speaks volumes about the yawning gap between the haves and have-nots in a country replete with natural resources. Darling's mental representation of America as a land of plenty where inhabitants lead a life free from want and worries feeds into an African utopian perception of the West as an Eldorado. The sense of anti-climax that grips Darling upon arriving in America is commensurate with her lofty expectations prior to departure from Paradise.

The merit of postcolonial writers' agency lies in their well-meaning call to use the plight of the waifs and straifs as a staple diet for their opus. This epitomizes a significant paradigm shift with regards to what obtained in the aftermath of independence, when the failure of statehood had pride of place in terms of fictional themes. Prospective migrants are mostly folks who live in skid row. In the world of We Need New Names, Darling and her friends (Godknow, Stina, Chipo, Sbho, Bornfree, Bastard) are a close-knit bunch who live by their wits, and whose miseries constitute a blistering indictment of postcolonial African leadership. Mismanagement of public funds and the pervasiveness of the dead hand of corruption as well as well as the stifling of freedom of expression spawn a climate of fear and anxiety that pushes Darling and her friends to mull over going down the road of migration. From the get-go, the young female narrator offers the reader interesting insights into the humdrum existence of parents who think nothing of whiling away time on peccadillos, thereby leaving their kids to their own devices:

Getting out of Paradise is not so hard since the mothers are busy with hair and talk, which is the only thing they ever do. They just glance at us when we file past the shacks and then look away. We don't have to worry about the men under the jacaranda either since their eyes never lift from the draughts. It's only the little kids who see us and try to follow, but Bastard just wallops the naked one at the front with a fist on his big head and they all turn back. (3-4)

Indeed, children's agency is bafflingly geared towards unsavoury acts such as stealing. The posh part of the country gone by the name of Budapest serves as a magnet for Darling and her gang. Darling underscores the significance of Budapest as a trough of sorts: "There are guavas to steal in Budapest, and right now I'd rather die for guavas. We didn't eat this morning and my stomach feels like somebody just took a shovel and dug everything out" (3). What marks Budapest off from Paradise is that it carries a colonial aura as its denizens are mainly white. Shades of the British occupation of Zimbabwe. There is more to the kids' visits to Budapest than mere guava stealing. The 'coloniality' of the district of Budapest with black folks working as security guards at lavish houses allows Bulawayo to achieve a two-pronged objective-that is, to scathingly rubbish the legacy of European colonialism as well as highlighting its use as a smokescreen to cloak poor governance cum failed leadership. The high-end district of Budapest acts as a foil to Paradise where inhabitants eke out a living in the face of overwhelming odds. This unconscionable dichotomy speaks to what Chikwanha-Dzenga et al. call "lack of correspondence between political and economic power" that, in their estimation, ruling party politicians cash in on at election time for their own self-serving ends (3). The impromptu police swoop on Budapest fits into the poisonous official narrative that casts Zimbabweans of white extraction as "the other" hell-bent on living off the sweat of the African masses. When the Assistant Police Commissioner Obey Marima hands a piece of paper to a white man, with the express brief to turf him out of his property along with his wife, he cannot help but snap: "Bloody nonsense! This is illegal, I won this fucking property, I have the papers to prove it... The white man starts tearing the paper in his hands; he rips it and rips it and rips it, throws the pieces onto the ground" $(119,121)$. The boss's comeback, on top of its vengeful undertones, brings to light a wildly warped perception of identity that feeds on racial exclusion: "Know this, you bloody colonist, from now on the black man is done listening, you hear? This is black-man country and the black man is in charge now. Africa for Africans" (120). The definition of identity formation does not rest on race or ethnicity-based intolerance. In a potent research paper, Bill Ashcroft, appositely writes that "the nation-state has been critiqued in post-colonial analysis largely because the post-independence, the postcolonized nation, that wonderful utopian idea, proved to be a focus of exclusion and division rather than unity", thereby "perpetuating the class divisions of the colonial state rather than liberating the national subjects" (12). The sense of belonging to a nation does not boil down to a matter of race. A nation "is a historically-produced multi-ethnic society" (Ashcroft 12-13) whose claim to homogeneity or purity conduces to a climate of nastiness on which intolerance and xenophobia thrive with unintended consequences. In "What is a Nation?" sophisticated late nineteenth-century French thinker, Joseph Ernest Renan debunks the trope of race as subservient to the identity of a nation, and underlines the commonality of Humanity:

The fact of race, a fact of the greatest moment at the outset, has always been diminishing. Race is not everything as it is amongst the rodents and felines and no one has the right to go about the world examining 
men's heads and then grabbing them by the throat saying, "You are our blood; you belong to us". Aside from this anthropological traits there is reason, justice, truth, and beauty, things that the same for all. (7)

The white man's pushback on Commissioner Marima's racism-tinged statement encapsulates a reproach to what Seamus Deane calls "insurgent nationalism":

I am an African, he says. This is my fucking country too, my father was born here, I was born here, just like you! His voice is so full of pain it's as if there is something that is searing him deep in his blood...The veins at the side of the white man's neck are like cords, his face dark with anger. But nobody minds him. They are leaving and storming into the house, their chants for Africa about Africans filling the air. (121)

Understandably, excruciating anger at being on the receiving end of wanton exclusion is writ large in the white man's comeback. Zimbabweans of African stock, doubtless, went through the gauntlet of British colonial subjugation. Granted. But those people belonging to the white minority who elected to stay in the country are part and parcel of the Zimbabwean social fabric. Little wonder that, in reply to Bastard's bafflement as to why Sbho is "crying for white people" as if they were his relatives, Sbho says witheringly, "They are people, you asshole!" (122). Disappointingly, Zimbabwe epitomizes glaringly a post-independence African nation where the white population serves as a scapegoat for the country's political, economic and social woes. In René Girard's book, a high-profile late French thinker, a key hallmark of scapegoating is its arbitrary edge. He points out in no uncertain terms the extent to which injustice underpins the plight of the scapegoat:

The victim or victims of unjust violence or discrimination are called scapegoats, especially when they are

blamed or punished not merely for the 'sin' of others, as most dictionaries assert, but for the tensions, conflicts,

and difficulties of all kinds. (qtd. in Davis 88).

To be sure, the construction of white subjectivity as a locus of political discrimination is nothing but a smokescreen to whitewash failed leadership. The political dispensation portrayed in the first half of We Need New Names points to dismally gross misgovernment that has spawned a pervasive disphoric atmosphere, so that the female narrator calls Zimbabwe "a kaka country". The abysmal connotation associated with this metaphoric term speaks volumes about the depth of social and economic suck gripping the country, leaving Darling to fantasize about a hunky-dory life in America where an aunt of hers lives as a migrant worker: "I'm not worried about that because when that time comes, I'll not even be here, I'll be living in America with Aunt Fostalina, eating real food and doing better things stealing" (12). If anything, generations of postindependence African youths feel hard done by. A bitter sense of betrayal over the ideals of the liberation wars cum the lofty expectations in the aftermath of statehood achievement plainly shines through their hard-hitting indictment of their leadership. Witness the conversation between folks reduced to homelessness after their houses have been razed to the ground by government bulldozers:

They shouldn't have done this to us, no, they shouldn't have. Salilwelilizwe leli, we fought to liberate this country. Wasn't it like this before independence? Do you remember how the whites drove us from our land and put us in those wretched reserves? I was there, you were there, wasn't it just like this? No, those were evil white people who came to steal our country and make us paupers in our country. What, but aren't you a pauper now? Aren't these black people evil for bulldozing your home and leaving you with nothing now?You are all wrong. Better a white thief to do that to you than your own black brother. Better a wretched white thief. (77)

The fag end of the foregoing is a measure of the anti-climactic sentiment gripping African over the crass failure of postindependence Africa to deliver the promises of the liberation war. Understandably, Simon Gikandi describes the postdecolonization era in Africa as "a great hoax" in that "Rather than bring the solace and succor it had promised, independence brought deepening misery and misfortunes" (498). He points out that the overnight change of the new crop of leaders from freedom fighters steeped in the challenges and pitfalls of nation-building to ruthless dictators with an eye on the main chance is the ultimate in political betrayal:

Worse still, the political space which was opened up by the struggle for independence and decolonization of the continent swiftly contracted as indigenous tyrants stepped into the shoes of the departing colonial masters. What made things more galling in one or two cases was the phenomenon of yesterday's freedom fighters who transformed overnight into civilian despots. (499)

It is against this nasty backdrop of despair and disenchantment as well as joblessness that massive flows of youths from Africa throng towards the supposedly greener pastures of Europe and America in a sometimes utopian quest for a better life. Witness how Darling stirringly depicts at length the desperation compelling large swathes of her compatriots to go down the bumpy route of migration:

Look at then leaving in droves, the children of the land, just look at them leaving in droves ... When things fall apart, the children of the land scurry and scatter like birds escaping a burning sky. They flee their own wretched 
land so their hanger may be pacified in foreign lands, their tears wiped away in strange lands, blistered prayers muttered in the darkness of queer lands. (147-8)

Oftentimes, the hopeful quest for a better life away from home turns out to be a damp squib. If anything, migration oftentimes goes hand in hand with utter multifaceted disillusionment, and an array of agonizingly painful travails germane to language, adaptation, alienation-you name it. The landscape of the migratory journey from home to final destination is dotted with insecurity and uncertainty, to say the least. Prominent amongst the harrowing experience of the migrant is the heartache of departing for ever one's country whether it be wittingly or forcefully, "leaving your country is like dying..." (122), says Stina. As it turns out, departing one's country means inherently forsaking one's home. Plainly, Home locates itself in a geographical space intertwined with a person's core identity. A concatenation of symbolic features resonate with home: birth, family, brotherhood, sisterhood, parentage and parenthood, friendship, neighborhood, or what not; so, the desperate choice to leave one's own turf to a new and alien one is, arguably, a fate worse than death. In David Ralph and Lynn A. Staeheli's estimation, "home contains variegated and overlapping aspects that are intimately related that shape identities and feelings of belonging" (518). The experience of migration with its attendant ordeals belie the representation of home as fixed and, accordingly, immune to change. Instead, it foregrounds "the simultaneity of home as sedentarist and mobile" (Ralph and Staeheli 518). The tack of the argument here is that migrants' conception of home as stable gets utterly disrupted in their new environment. In the host country, immigrants associate home with nefarious selfishness and xenophobia as well as difficulties of integration in contradistinction to their notion of home in their place of origin as a cocoon where the feeling of belongingness is a given. Darling exemplifies the type of migrant compelled to have a thorough rethink of her notions of home and identity.

Much as she performs well at school -"getting all As in everything, even maths and science" (167)-, the fact remains that Darling has her work cut out fitting in. She confesses to being on the brink of wishing to pass on because of her anger at "the other kids" who "teased me about my name, my accent, my hair, the way I talked or said things, the way I dressed, the way I laughed" (167). To her great amazement, she has not been able to get any tip as to how to get off the hook when she has opened up to Aunt Fostalina about her experience. Then she turns the clock back, conjuring up happy memories back home as a bulwark: "When I was growing up back home we only got new clothes on Christmas and turned out just fine; back home you wouldn't ever dream of talking to your elders in that tone; back home this, back home that" (167-8). This echoes what Edward Said calls the "double perspective" into which the migrant taps by way of a coping strategy:

Because the exile sees things both in terms of what has been left behind and what is actual here and now, there is a double perspective that never sees things in isolation. Every scene or situation in the new country necessarily draws on its counterpart in the old country. Intellectually this means that an idea or experience is always counterpoised with another, therefore making both appear in a sometimes new and unpredictable light...(60)

Deserving elaboration is the significance of migratory experience as a site for negotiating transnational subjectivities. The migrant subject is, from a postcolonial vantage point, a marginal who strives flat out to forge a new subjectivity far away from home in the face of overwhelming odds. According to Hans Mol, marginality "refers to persons or groups of persons who stand on the boundary of larger groups or societies neither completely belonging nor suffering outright rejection from them" (31-2). The migrant is caught up between two worlds the commonality of which is hostility-that is, his new setting where he is the butt of rejection due to the colour of his skin and his place of origin where the harsh social, economic and political context makes life a hellhole. Hence the sense of divided self or 'hybridity ${ }^{3}$ ' that distinctively marks the migrant. To be sure, 'Hybridity' can take on many forms, not least linguistic which has pride of place in Bulawayo's novel. After the fashion of many a migrant, Darling's most excruciating ordeals in her society of adoption pertains to language barrier. Her lack of English constitutes, indeed, a drag on her all-out drive to fit in. The overly obnoxious wall of rejection cum exclusion that sets migrants apart from the host community gets thicker and so even more difficult to climb over as language affords the possibility of feeling a sense of belonging. Witness the impassioned way in which Darling airs her resentment over her inability to resort to her mother tongue to express her gut feelings:

Because we were not in our country, we could not use our own language, and so when we spoke our voices came bruised. When we talked, our tongues thrashed madly, staggered like drunken men. Because we were not using our languages we said things we did not mean; what we really wanted to say remained folded inside, trapped. In America, we did not always have the words. It was only when we were by ourselves that we spoke in our voices. (242)

Incidentally, Darling's shift from "I" to "we", depending upon circumstances, is a means of foregrounding the universal character of the discontents attendant upon the migratory experience. An array of commonalities binds migrants. (The resort to the collective subject pronoun "we" is front and center in the chapter entitled "How They Lived", where the narrating voice describes at length the travails of migrants from the Third World with regards to immigration officials and the sacrificial lengths to which they went to come to America.) Faced with the grim prospect of abandoning his/her mother tongue, the migrant cannot help but feel a sense of loss compounded by the centrality of language to subjectivity. If anything, language is the bedrock to a person's identity. It is thanks to one's language that one somewhat becomes a social being and, more significantly perhaps, passes down one's mores to one's descendants. Cognizant of "the critical role of language in the construction of selfhood and otherness", Kenyan top-flight thinker Ngữğ wa Thiong'o is at pains to underscore how memory and language are woven into a whole, and how language has the potential for standing in the way of identity construction: 
"memory and consciousness are inseparable. But language is the means of memory, or, following Walter Benjamin, it is the medium of memory. It is here, in memory's very medium that the various movements' quest for wholeness seriously falters" (40-1). Then he goes on to elaborate upon the way in which the twosome feeds into the circle that the diasporic writer has his way cut out squaring:

The problem of language and memory presents itself differently for the writers of the diaspora and of the continent. In the diaspora, the question is this: how do you raise buried memory from the grave when the means of raising it are themselves buried in the grave or suffocated to the level of whispering ghosts. (42)

Language can hamper the migrant subject's halting steps towards integration into the host society. His all-out agency revolves around devising an effective tool in a desperate bid to ride above the integration-related hassles spawned by language inaccessibility. Actually, the harrowing experience of migration frames the migrant as a postcolonial subject conspicuous by his bouncebackability and resistance. The migrant's pushback carries, as it were, no vengeful overtones. Rather, it is all-encompassing in that it rules out "rejection of dominant culture, the utter refusal to countenance any engagement with its forms and discourses" (Ashcroft 47). The migrant's enactment of resistance to the host society's strenuous attempts to frame him as an 'other', a nonentity clicks into Bill Ashcroft's notion of 'Interpolation' which is a ploy that "involves the capacity to interpose, to intervene, to interject a wide-range of counter-discursive tactics into the dominant discourse without asserting a unified anti-imperial intention, or a separate oppositional purity" (47). This echoes Darling's coping strategies when it comes to her lack of English:

I have decided the best way to deal with it is to sound American, and the TV has taught me just how to do it.

It's pretty easy; all is you have to do is watch Dora the Explorer, The Simpsons, SpongeBob, Scooby-Doo, and then you move on to That's so Raven, Glee, Friends, Golden Girls ${ }^{4}$, and son on, just listening and imitating the accents ... The TV has also taught me that if I'm talking to someone, I have to look him in the eye, even if it is an adult, even if it's rude. (196)

Darling's no-nonsense attempts to draw upon aspects of the dominant culture with an eye to achieving transformative ends also finds expression in the scene when she, Marina and Kristal (her Nigerian and Afro-American friends) watch porn flicks the moment they come back from school $(201,202,203,204)$. Of note is the fact that mindset change oftentimes goes with the territory of migratory experience as "new experiences result from the coming together of multiple influences and peoples, and these new experiences lead to altered or evolving representations of experience and of self-identity" (White 1). More significantly, "such representations are then manifest in cultural artifacts of many kinds-new forms of dress, of food cultures and of consumerism, new styles of music and of poetry, new political ideologies, new forms of literary production" (White 1). In We Need New Names, the mentality shift that is associated with the act of migration shines through the female narrator's thrill as she along with her said friends do the rounds of such glitzy department stores as JCPenny and Best Buy (226-233). She is overwhelmed, and even comes near to freaking out upon seeing her dream car. A Lamborghini, that is, but the hefty price turns her off (226). The relentless drive on the part of the migrant subject to integrate into the host society has the potential for alienating him from his belief systems. Actually, the sense of "unbelonging" stemming from the heartache of exclusion and rejection based on meaningless preconceived ideas can compel the migrant to try and espouse the cultural mores of the country of settlement. As Darling starts to go overboard on American modern conveniences as well as her attire -"I am the one wearing something different, a V-neck with a French flag on my stomach"-, her friend Marina somewhat cuts her down to size: "You could have at least wore (sic) something with an African flag" (233). Her attempts at mimicry for the sole purpose of fitting in fizzle out. The fact of being constantly reminded through words or otherwise that he does not belong in his society of adoption impinges on the migrant's psyche. Edward Said appositely writes:

The fact is that for most exiles the difficulty consists not simply in being forced to live away from home, but rather, given today's world, in living with the many reminders that you are in exile, that your home is not in fact so far away, and that the normal traffic of everyday contemporary life keeps you in constant but tantalizing and unfulfilled touch with the old place. The exile therefore exists in a median state, neither completely at one with the new setting or fully disencumbered of the old, beset with half-involvements and half-detachments, nostalgic and sentimental on one level, an adept mimic or a secret outcast on another. (48-9)

Here, Said emphasizes one of the most obnoxious discontents of the migratory experience. Being reminded of your "otherness" at every turn can spawn trauma that might easily lead you to develop low self-regard. It is indeed part of the migrant's experience to swallow race-based affronts on a regular basis with next to no possibility to put up pushback. This is due to the migrant subject's unflattering status as an "illegal alien" in the words of the narrator. On page 1 of the chapter entitled "How They Lived", the reader gets a sense of racism-spiked unconscionable innuendoes that the likes of Darling are on the receiving end of from some Native Americans:

And when they asked us where we were from, we exchanged glances and smiled with the shyness of child brides. They said, Africa? We nodded yes. What part of Africa? We part of Africa? Is it that part where vultures wait for famished children to die? We smiled. ... Is it where dissidents shove AK-47s between women's legs? We smiled. Where people run about naked? ... Is it where the old president rigged the election and people were tortured and killed and a whole bunch of them put in prison and all, there where they are dying of cholera-oh my God, yes, we've seen your country; it's been on the news. (239-240)

The fag end of this racist slur personally hit home for Darling. Although her country of origin is not overtly mentioned, there is no denying that Zimbabwe and its ruler is being hinted at. Robert Mugabe, that is, rose to power in 1980 in the 
aftermath of a long-drawn out bloody liberation war pitting Zimbabwean freedom fights and forces of the Rhodesian government then led by Ian Smith. Cornered into resignation in 2017 following a thirty-seven-year spell in power, Mugabe (who passed away on 6 September 2019) can be credited with a good record in terms of infrastructure, e.g. hospitals, schools, roads. Notwithstanding, he turned a despot at the turn of the 1990s, with a marked propensity for stifling any dissenting voice under the guise of a fight against Zimbabwean foes both inside and outside of the country. Not surprisingly, the title of the novel under review captures a sense of longing for an ideal that NoViolet Bulawayo voices in an interview:

I wrote the novel at a specific time in my country's history. Recent history, I should say, when the country was coming undone, due to failure of leadership. And by saying "we need new names" I was speaking for the need for us as a people to sort of re-imagine, rethink ourselves, think about where we were going. We needed new ways of seeing things, new ways of doing things, new leadership. It was basically a call for renewal. But it should not be confined to Zimbabwe. I believe you can translate across borders. (Interview with NoViolet Bulawayo)

Harking back to Darling and her fellow migrants, they feel hard-done by. Bruised to the core from the sickening humiliation of being the butt of such glaring psychological torture informed by a racist ideology, the female narrator and her friends can't find it in their hearts to keep their cool any longer. Just like that the sheepish smiles turn into crying:

Our smiles melted like dying shadows and we wept; wept for our blessed, wretched country. We wept and wept and they pitied us and said, It's okay, -it's okay, you are in America now, and we still wept and wept and they gave us soft little thingies and said, Here is some Kleenex, here, and we took the soft thingies and put them in our pockets to look at later and we wept still, wept like widows, wept like orphans. (240)

Such discourses as made the migrants cry their heart out are a throwback to the colonial era. The nefarious narrative as to the ineluctability of colonization was shaped around the supposed need for Africans to be civilized in that they inhabited a land untouched by the lights of civilization. The centuries-long subjection of Africa and its people to the jackboot of colonial oppression could admit of no resistance to what was termed "a civilizing mission". Key to the success of the colonial enterprise, it bears stressing, was the wanton destruction of the cultural heritage of indigenous Africans. Kenyan prominent thinker, Ngügı̌ wa Thiong'o, forcefully argues that colonization's "most important area of domination was the mental universe of the colonized", namely "the control, through culture, of how people perceived themselves and their relationship to the world" (16). The postcolonial writer seeks to strenuously debunk those old-school shibboleths that underpin the ideology of colonization. Thus, in a laudable endeavour to "give expression to colonized experience", postcolonial writers take it upon themselves to "undercut thematically and formally the discourses which supported colonization-the myths of power, the race classifications, the imagery of subornation" (Boehmer 3). Little wonder that migration (which is a conspicuous hallmark of the postcolonial era) has, from a thematic perspective, pride of place in postcolonial writing. Migration literature's staple diet is the distress of the downtrodden whose experience it sets out to chronicle. Those folks, that is, who "have suffered the sentence of history", meaning "subjugation, domination, diaspora, displacement" (Bhabha 246). By so doing, migration postcolonial literature gives them a voice. Sam Durrant writes that "postcolonial narrative presents itself as a mode of mourning, as a way of consciously working through history" (11). The enactment of mourning reflects the writer's own way to castigate a history of wrongs informed by a racist ideology. Also, it betokens the impossibility for the postcolonial writer to utterly put the past to rest as its dehumanizing effects linger to this day.

The uncertainty of displacement conflates with the nagging wistful memories of home to cripple the migrant's effort to work out a new subjectivity. The migrant subject is, actually, caught between the rock of the quasi impossibility to go back home and the hard plate of his rejection in the host society. Hence the ambivalence that characterizes the migrant's position:

A common feature of many migrants and migrant cultures is ambivalence. Ambivalence towards the past and the present as to whether things were better "then" or "now". Ambivalence towards the future: whether to retain a "myth of return" or to design a new project without further expected movement built in. Ambivalence towards the "host" society: feelings of respect, dislike or uncertainty. Ambivalence towards standards of behaviour: whether to cling to the old or discard it, whether to comprise via symbolic events whilst adhering to the new on an everyday basis. (White 3-4)

The migrant subject goes through the gamut of acute emotional trauma born out of the disillusionment that more often than not attends the utopian quest for a better life overseas. Only when the discrepancy of the lofty expectations of migration and the reality on the ground hit home, does the migrant start habouring the idea of going back home. Still this idea of return is oftentimes a pie in the sky. Witness how the female narrator describes the double bind she and her fellow migrants find themselves in with no easy way out: "We did not go back home because we did not have the papers for our return, and so we just stayed, knowing that if we went we would not be able to reenter America" (248-9). The female narrator likens her country of adoption to a prison. In the same vein, nevertheless, she feels it to be a prison whose perks, so to speak, far outweigh the warmth and cocoon of "home": "We stayed, like prisoners, only we choose to be prisoners and we loved our prison; it is not a bad prison. And when things only got worse in our country, we pulled our shackles even tighter and said, we are not leaving America, no, we are not leaving America" (249). The path to migration pretty much offers no off-ramp to returning home. The migrants wisely elect to stick it out in their host society rather than go down the path of uncertainty represented by home return. From a philosophical vantage point, the migrants' attitude espouses the principle of utility ${ }^{5}$. The 
migrants' preference for their host society where you are the butt of racist cum xenophobic slur encapsulates, doubtless, an indictment of postcolonial African leadership.

Migration and exile are two sides of the same coin. They share a "condition of terminal loss" the harrowing nature of which stems from being "the unhealable rift between a human being and a native place, between the self and its true home" (Said 180). Despondency and memory of home are inscribed on the untoward predicament of the migrant subject. The latter is entangled in a web of travails, not the least of which is disillusionment. Prior to departure, the would-be migrant visualize migration as a way out of a life of misery. But the reality facing him on the ground grows to prick his bubble. Darling's sense of anti-climax over the disconnect between how she fancied life in America back home and what she saw upon arrival is writ large:

And when we got to America we took our dreams, looked at them tenderly as if they were newly born children, and put them away; we would not be pursuing them. We would never be the things that we had wanted to be: doctors, lawyers, teachers, engineers. No school for us. (243)

Indeed, Darling as well as her comrades in distress- whom she refers to as "others with names like myths, names like puzzles names we had never met before: Virgilio, Balamuggunthan, Faheem, Abdulrahman, Aziz, Baako, Dae-Hyun, Ousmane, Kimatsu" (245) threw everything in the kitchen sink in the hope of fulfilling their dream of a better life in America, only to be met with disenchantment. Disillusionment, against a backdrop of migratory experience, means being reduced to scraping over the bottom of the barrel in terms of jobs so as to get by:

We worked with dangerous machines, holding our breath like crocodiles underwater, our minds on the money and never on our lives. Adamou got murdered by that beast of a machine that also ate three fingers of Sudan's left hand. We cut ourselves working on meat; we got skin diseases. We inhaled bad smells until our lungs thundered. Ecuador fell forty stories working on a roof and shattered his spine, screaming, Mis hijos! Mis jijos! On his way down. We got sick but did not go to hospitals, could not go to hospitals. We swallowed every pain like a bitter pill, drank every fear like a love potion, and we worked and worked. (246)

The frenzied anticipation of a hunky-dory situation translates into a nightmarish hellhole. The migratory experience is a window upon the dangers of overweening expectations. Actually, nineteenth-century German thinker, Arthur Schopenhauer, cautions us against excited anticipation of the future:

Every immoderate joy....always rests on the delusion that one has found in life what can never be found therelasting satisfaction of the harassing desires and cares, which are constantly breeding new ones. From every particular delusion of this kind one must inevitably be brought back later, and then when it vanishes must pay for it with pain as bitter as the joy its entrance caused was keen. (410)

Migration literature is, it bears testimony, an eye-opener. It is a literature that blows the lid off a wide range of horrors attendant upon the condition of the migrant. Its wholesome potency lies in the courageous move to lay bare the psychological cum physical wounds wreaked by living away from home. If anything, behind the life of every migrant subject there is a gruesomely heartrending story of lack, marginalization, exclusion, nostalgia-you name it. Edward Said writes that "the literature about exile objectifies an anguish and a predicament most people rarely experience firsthand" (182). He goes on to highlight human responsibility for displacement and, more significantly, construes migration as a fate worse than death: "exile is produced by human beings for other human beings; and that, like death but without death's ultimate mercy, it has torn millions of people from the nourishment of tradition, family, and geography" (182). As it turns out, from a postcolonial vantage point, migration is a by-product of both colonial actualities and, perhaps more significantly, post-independence African leadership failure. Indeed, the latter's proclivity, upon rising to power, for busying themselves to feather their nest rather working like hell to effect change in the masses' everyday life and foster good governance as a recipe for development.

In the final analysis, suffice to say that We Need New Names is a sobering primer on the human toll of migratory experience. To boot, it serves as a cautionary tale on the cloud cuckoo land of the act of migration as a sure fire way out of destitution. Through the lead character's moral and physical travails, NoViolet Bulawayo foregrounds the universality of poverty as well as suffering. Even in the nations at the cutting edge of development, there are pockets of poverty. The enactment of migration may stem from excruciating despair but is not a foolproof remedy for it. Rather, it lies bare inter alia the cultural and linguistic dehumanization, as it were, of the 'Other' that the migrant subject is the epitome of. The desperate quest for a better life abroad results more often than not in sheer disillusionment. The world that is being indicted and rejected in We Need New Names is that of post-colonial African leaders whose gross betrayal of the ideals of independence is the main driver of the continuous flux of movements of young people from Africa to the West, as well the ideology of racism and xenophobia.

\section{References}

Ashcroft, B. (2009). Beyond the Nation: Post-colonial Hope. The Journal of the European Association of Studies on Australia, 1(1), 12-22.

(2001). Post-colonial transformation. Psychology Press.

Ascroft, B., Griffiths, G. and Tiffin, H. (1989). The Empire Writes Back. New York: Routledge

Bhabha, H. K. (1994). The Location of Culture. London and New York: Routledge

Bentham, J. (1789) [2000]. An introduction to the Principles of Morals and Legislation. Batoche Books Kitchener 
Boehmer, E. (2005). Colonial and Postcolonial Literature: Migrant Metaphors. Oxford University Press on Demand.

Bulawayo, N. (2013). We Need New Names. New York: Back Bay Books.

Chikwanha-Dzenga, A. B., Masunungure, E., \& Madzingira, N. (2001). Democracy and National Governance in Zimbabwe: A Country Survey Report. Michigan State University, Department of Political Science.

Foster, R. P. (2001). When Immigration is Trauma: Guidelines for the Individual and Family Clinitian. American Journal of Orthopsychiatry, $71(2): 153-170$.

Gikandi, S. (2003). Encyclopedia of African Literature. London and New York: Routledge

King, R., Connelle, J., and White, P. (1995). Writing across Worlds: Literature and Migration. London and New York, Routledge

Mol, J. J. (1963). The Function of Marginality. International Migration, 1(3), 175-177.

Moore-Gilbert, B. (1997). Postcolonial Theory: Contexts, Practices, Politics. New York: Verso

Mostikov, S. V. (2015). Correlation of Migration Processes and the Social Concept of "Home". Journal of Siberian Federal University. Humanities and Social Sciences 9 (8): 1990-1997.

Shands, K. W. (2008). Neither East nor West: From Orientalism to Postcoloniality. In Kerstin W. S. (ed). Neither East nor West: Postcolonial Essays on Literature, Culture and Religion. Sweden: Flanders.

Ramachandra, V. (2008). Subverting Global Myths: Theology and the Public Issues Shaping the World. Downers Grove, Illinois

Renan, E. J. (1882). "What's a Nation?”, A conference lecture delivered in Sorbonne on March 11th, 1882, Paris, PressesPocket. Trans. Ethan Rundell (1992)

Ralph, D., \& Staeheli, L. A. (2011). Home and Migration: Mobilities, Belongings and Identities. Geography Compass, 5(7), 517-530.

Said, E. (1996). Representations of the Intellectual: The 1993 Reith Lectures. New York: Vintage Books: A Division of Random House

....... (2013). Reflections on Exile: and Other Literary and Cultural Essays. Granta Books.

Spickard, P. (2009). Almost Aliens: Immigration, Race, and Colonialism in American History and Identity. New York: Routledge

Walkowitz, R. L. (2010). Immigrant Fictions: Contemporary Literature in an Age of Globalization. Wisconsin: The University of Wisconsin Press

Wa Thiong'o, N. (2009). Something Torn and New: An African Renaissance. New York: Basic Civitas Books (2001). Decolonizing the Mind: The Politics of Language in African Literature. Oxford, London

\title{
Endnotes
}

\begin{abstract}
${ }^{1}$ In an article entitled «When Immigration Is Trauma : Guidelines for the Individual and Family Clinician”, Rosemary Perez Foster identifies four crushingly traumatic stages associated with migration: pre-migration trauma by which he means "events experienced just prior to migration that were a chief determinant of the relocation"; trauma during transit to the new country; "continuing traumatogenic experiences during the process of asylum-seeking and resettlement". This stage appertains to the often squalid conditions in which immigrants live in their host countries pending the end of the asylum-seeking applications, especially if the new destinations "are themselves economically hard-pressed and receive immigrants in large numbers, in wartime, or as a result of some environmental or geopolitical crisis"; and, finally, "sub-standard living conditions in the host country due to unemployment, inadequate support, and minority persecution". In the host country, the immigrant runs through the gauntlet of no end of ordeals amongst which feature prominently "employment issues, inadequate living conditions, and the need to rebuild social networks" (155-6). In Foster's estimation, all these stages factor into the psychological distress of immigrants.

${ }^{2}$ Migration literature or immigration fiction or migrant literature is a novelistic genre whose trademark is its emphatic description of the experience of migration. Leslie Andelson quoted by Rebecca Walkowitz argues that "the literature of migration would have to include all works produced in a time of migration or that can be said to reflect on migration" (533). To put it differently, the subject matter of migrant literature is germane to the immigration experience.

${ }^{3}$ This term enjoys currency big time in post-colonial discourse theory. Doubtless, 'hybridity' is a derogatory term used to label miscegenation, viz. "the sexual union of different races, specifically whites with negroes" (Ashcroft et al 127). From a colonial setting perspective, the slippery concept of 'hybridity' "commonly refers to the creation of new transcultural forms within the contact zone produced by colonization" (108). In layman terms, the hallmark of 'hybridity' is its mixture of two different elements. It came to considerable prominence in post-colonial discourse theory thanks to a high-profile pundit on post-colonial discourse- that is, Homi Bhabha. Drawing from literature and critical theory, Bhabha is at pains to demonstrate how colonial society provides the opportunity for new cultural identities to be formed. His notion of 'cultural hybridity' is his well-meaning attempt to debunk any idea of authenticity with regards to culture and identity: "Cultures are never unitary in themselves, nor simply dualistic in their relation of Self to Other" (52). In Bhabha's estimation, multicultural settings are an ideal site for successfully negotiating cultural difference in the spirit of forging new subjectivities, that is, "elaborating strategies of selfhood -singular or communal- that initiate new signs of identity, and innovative site of collaboration, and contestation, in the act of defining the idea of society itself" (2). Bhabha calls "The Third Space" or "Liminal space" those locations where attempts to cut across the cultural divide and embark upon a process of "symbolic interaction" that culminates in cultural blending are made. The value of "cultural hybridity', contends Bhabha", lies in the fact that it "entertains difference without an assumed or imposed hierarchy” (248).
\end{abstract}




\begin{abstract}
${ }^{4}$ Italicized in the text; it is I who underline.
${ }^{5}$ Jeremy Bentham is an Enlightment-age British thinker. Key to his philosophy is what he calls "the principle of utility". From the get-go, Bentham in his An Introduction to the Principles of Morals and Legislation (1780) makes a point of contending that "Nature has placed mankind under the governance of tow foreign matters (sic), pain and pleasure" (Italicized in the book; so, it is I who underline). He expounds on the backbone of the utility principle as follows: "By utility is meant that property in any object, whereby it tends to produce benefit, advantage, pleasure, good, or happiness (all this in the present café comes to the fame thing) or (what comes again to the fame thing) to prevent the happening of mischief, pain, evil, or unhappiness to the party whole interest is considered: if that party be that community in general, then the happiness of the community: if a party individual, then the happiness of the individual" (II). Bentham posits that any human action is measured by the amount of pain it seeks to avoid or the amount of happiness it seeks to produce. An individual embarks upon a course of action that is supposed to yield him happiness or spare him pain: "A man may be fair to be a partisan of the principle of utility, when the approbation of disapprobation he annexes to any action, or to any measure, is determined by and proportioned to the tendency which he conceives it to have to augment or diminish the happiness of the community: or, in other words, to its conformity or unconformity to the laws of dictates of utility" (III-IV). Harking back to We Need New Names, the female narrator's misgivings about going back home as opposed to staying in the US (even though she runs through the gauntlet of no end of race-based hassles) can find meaning in the principle of utility.
\end{abstract}

